\title{
Serum Hyaluronan Concentration Determined by Radiometric Assay in Patients with Pretibial Myxedema and Graves' Ophthalmopathy
}

\author{
Yumi IMAI, Ritsuko ODAJIMA*, TAEKo SHIMIZU \\ AND YoshIMASA SHISHIBA
}

\begin{abstract}
Division of Endocrinology, Endocrine Research Laboratory*, Toranomon Hospital, 2-2-2, Toranomon, Minato-ku, Tokyo 105, Japan
\end{abstract}

\begin{abstract}
The serum concentration of hyaluronan (HA) was measured by radiometric assay in patients with pretibial myxedema (PTM) and Graves' ophthalmopathy $(\mathrm{GO})$. The mean HA concentration in the patients $(\mathrm{n}=8)$ was $21.2 \pm$ 15.3 (mean $\pm \mathrm{SD}) \mu \mathrm{g} / 1$, while that of Graves' disease without skin or eye involvement $(\mathrm{n}=7)$ was $23.5 \pm 11.0($ mean $\pm \mathrm{SD}) \mu \mathrm{g} / 1$ and that of the control $(\mathrm{n}=8)$ was $25.5 \pm 16.4($ mean $\pm \mathrm{SD}) \mu \mathrm{g} / 1$.

We conclude that local accumulation of glycosaminoglycan in PTM or GO is not associated with an increase in the serum HA concentration.
\end{abstract}

Hyaluronan (HA) is one class of glycosaminoglycan (GAG) found ubiquitously in connective tissue. Metabolic studies reveal that HA enters the blood via the lymph vessels (Laurent et al., 1981) and is rapidly eliminated by the endothelial cells of the liver (Fraser et al., 1981 ; Smedsrod et al., 1984). Therefore, the serum concentration of HA could be an indicator of HA overproduction in connective tissue and of impairment of its catabolism in the liver (Engström-Laurent et al., 1985). A recently developed radiometric assay for HA has remarkably improved the sensitivity of the assay, making it possible to investigate the serum concentration of $\mathrm{HA}$ in pathological Received August 14, 1990

This study was supported in part by grant \#1288635 from the Ministry of Education, Science and Culture and also in part by a grant for the Study in Receptor Abnormality, from the Ministry of Health and Welfare, Japan. states (Tengblad, 1980). By means of this technique, Engström-Laurent et al. found an increase in serum HA in patients with rheumatoid arthritis (RA) which seems to be due to enhanced production of $\mathrm{HA}$ in inflamatory joints (Engström-Laurent et al., 1987).

The accumulation of GAG including HA in affected loci is a major pathological change in pretibial myxedema (PTM) and Graves' ophthalmopathy (GO) (Smith, T. J. et al., 1989). We therefore investigated whether the accumulation is associated with the increase in the serum HA concentration or not in patients with PTM and GO.

\section{Methods}

Serum samples were obtained from 1 patient with PTM, 6 patients with GO and 1 patient with PTM and GO whose clinical date are 
Table 1. Clinical data of patients with pretibial myxedema (PTM) and Graves' ophthalmopathy (GO)

\begin{tabular}{|c|c|c|c|c|c|c|c|c|c|c|}
\hline \multicolumn{4}{|c|}{ Patients } & \multicolumn{3}{|c|}{ Thyroid function test } & \multicolumn{4}{|c|}{ Duration of } \\
\hline No. & $\begin{array}{l}\text { Age } \\
(\mathrm{yr})\end{array}$ & $\operatorname{Sex}$ & $\begin{array}{l}\text { Type of } \\
\text { disease }\end{array}$ & $\begin{array}{c}\mathrm{T}_{4} \\
(\mu \mathrm{g} / \mathrm{d} 1)\end{array}$ & $\begin{array}{c}\mathrm{T}_{3} \\
\text { (ng/d1) }\end{array}$ & $\begin{array}{c}\text { TSH } \\
(\mu \mathrm{U} / \mathrm{ml})\end{array}$ & $\begin{array}{l}\text { TBII } \\
(\%)\end{array}$ & $\begin{array}{l}\mathrm{GD}^{\mathrm{b}} \\
(\mathrm{mo})\end{array}$ & $\begin{array}{c}\text { PTM/ } \\
\text { GO } \\
(\mathrm{mo})\end{array}$ & $\begin{array}{l}\text { Hya- } \\
\text { luronan } \\
(\mu \mathrm{g} / 1)\end{array}$ \\
\hline 1 & 19 & $\mathbf{M}$ & GO & 9.9 & 170 & 0.022 & 15 & 0.8 & 0.8 & 7.8 \\
\hline 2 & 39 & $\mathrm{~F}$ & GO & 8.1 & 88 & 0.568 & 3.4 & $0^{\mathrm{c}}$ & 19 & 20.5 \\
\hline 3 & 43 & $\mathrm{~F}$ & GO & 7.5 & 112 & 1.610 & 59 & 24 & 2 & 31.0 \\
\hline 4 & 44 & $\mathbf{M}$ & PTM & 11.9 & 170 & 0.0888 & 75.3 & 5 & 6 & 4.7 \\
\hline 5 & 45 & $\mathrm{~F}$ & GO & 8.2 & 150 & 7.47 & 一 $^{\mathrm{a}}$ & 61 & 1.5 & 13.6 \\
\hline 6 & 56 & $\mathrm{~F}$ & GO & 8.6 & 166 & 0.0779 & 43.6 & 1 & 2 & 27.8 \\
\hline 7 & 61 & M & GO/PTM & 7.3 & 118 & 0.154 & 74 & 11 & 1 & 9.8 \\
\hline 8 & 62 & $\mathrm{~F}$ & GO & 90 & 121 & 1.96 & -6.1 & $0^{\mathrm{c}}$ & 1.5 & 54.0 \\
\hline \multicolumn{3}{|c|}{ Normal range } & & $6-11$ & $60-200$ & $0.5-5.5$ & $<30$ & & & \\
\hline
\end{tabular}

a $-=$ Not examined ${ }^{\mathrm{b}} \mathrm{GD}=$ Graves' disease ${ }^{\text {c }} 0=$ Euthyroid Graves' ophthalmopathy

summarized in Table 1. All GO patients had proptosis or extraocular muscle dysfunction. None had received any immunosuppressive therapy, systemic steroid therapy or topical steroid therapy for skin or orbit. Serum samples were also obtained from 7 patients with Graves' disease (GD) without skin or eye involvement (4 males and 3 females, aged 28-61 years). All GD patients were thyrotoxic without any treatment, as summarized in Table 2 . As the control, serum samples obtained from 8 normal subjects ( 3 males and 5 females aged 25-61 years) were also assayed. All samples were stored at $-20^{\circ} \mathrm{C}$ until analysis. The serum concentration of each hormone was measured by radioimmunoassay with commercial kits $\left(\mathrm{T}_{4}\right.$ and $\mathrm{T}_{3}$, Eiken Chemical Co.; TSH, Daiichi Radioisotope Labs.). TBII was measured by radio- receptor assay with commercial kit (Bakster). The hyaluronan concentration was measured with Pharmacia HA 50R kits (Pharmacia, Sweden) whose principles were previously outlined by Engström-Laurent et al., (Engström-Laurent et $a l .$, 1985). In short, hyaluronate binding protein (HABP) which has specific affinity for $\mathrm{HA}$ is radiolabeled and is used as a radiolabeled ligate. $\mathrm{HA}$ in the sample binds to ${ }^{125}$ I-HABP in a manner dependent on the concentration. Unbound ${ }^{125}$ I-HABP was absorbed to HA immobilized onto Sepharose. The procedure employed is as follows.

At first, $100 \mu 1$ of serum or standard is allowed to bind $200 \mu \mathrm{l}$ of ${ }^{125} \mathrm{I}$-HABP for $60 \mathrm{~min}$ at room temperature. Then $100 \mu$ of HA Sepharose is added to absorb free ${ }^{125}$ I-HABP. After incubation for $45 \mathrm{~min}$ at room temperature, $2 \mathrm{ml}$

Table 2. Clinical data of patients with Graves disease (GD)

\begin{tabular}{|c|c|c|c|c|c|c|c|}
\hline \multicolumn{3}{|c|}{ Patients } & \multicolumn{3}{|c|}{ Thyroid function test } & \multirow[b]{2}{*}{$\begin{array}{l}\text { TBII } \\
(\%)\end{array}$} & \multirow[b]{2}{*}{$\begin{array}{c}\text { Hyaluronan } \\
(\mu \mathrm{g} / 1)\end{array}$} \\
\hline No. & $\begin{array}{l}\text { Age } \\
(\mathrm{yr})\end{array}$ & Sex & $\begin{array}{c}\mathrm{T}_{4} \\
(\mu \mathrm{g} / \mathrm{d} \mathrm{l})\end{array}$ & $\begin{array}{c}\mathrm{T}_{3} \\
(\mathrm{ng} / \mathrm{d} \mathrm{l})\end{array}$ & $\begin{array}{c}\text { TSH } \\
(\mu \mathrm{U} / \mathrm{ml})\end{array}$ & & \\
\hline 1 & 28 & $\mathbf{M}$ & 19.5 & 327 & 0.081 & 10 & 8.1 \\
\hline 2 & 28 & $\mathrm{~F}$ & 29.6 & 529 & 0.061 & 51 & 17.5 \\
\hline 3 & 42 & $\mathrm{~F}$ & 24.4 & 664 & 0.138 & 43 & 44.8 \\
\hline 4 & 46 & $\mathbf{M}$ & 17.8 & 318 & 0.128 & 61 & 14.4 \\
\hline 5 & 47 & $\mathbf{M}$ & 26.7 & 447 & 0.046 & 10 & 25 \\
\hline 6 & 53 & $\mathbf{M}$ & 14.1 & 359 & 0.106 & 66.6 & 28.4 \\
\hline 7 & 61 & $\mathrm{~F}$ & 13.5 & 207 & 0.173 & 2 & 26 \\
\hline \multicolumn{3}{|c|}{ Normal range } & $6-11$ & $60-200$ & $0.5-5.5$ & $<30$ & \\
\hline
\end{tabular}




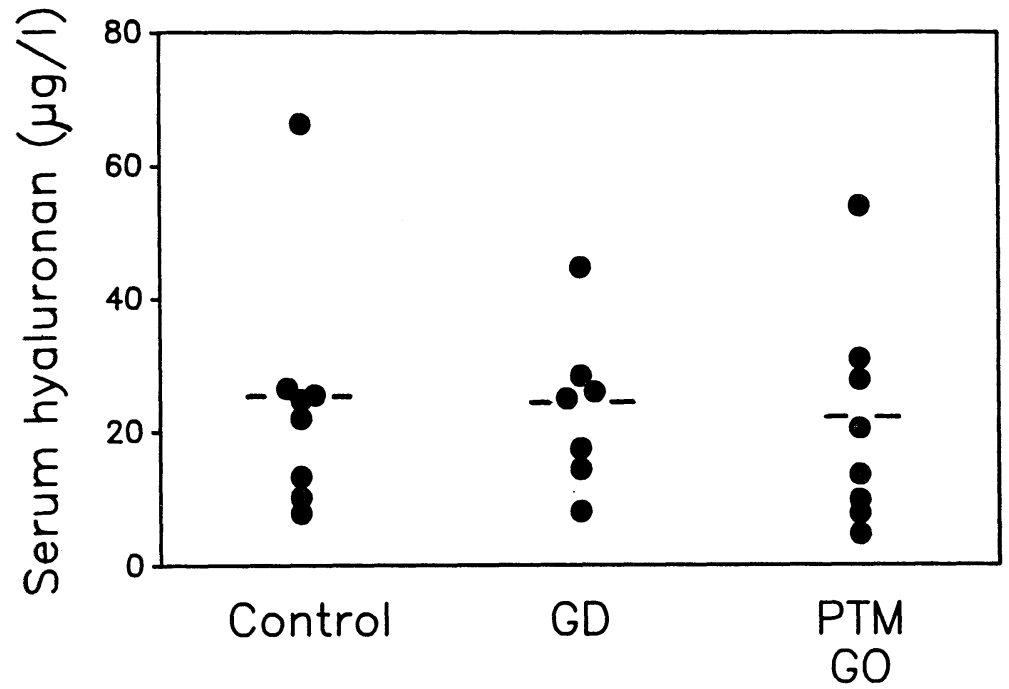

Fig. 1. The serum hyaluronan concentration in pretibial myxedema (PTM) or Graves' ophthalmopathy (GO), Graves' disease without skin or eye involvement (GD) and the control.

of decanting solution is added. ${ }^{125}$ I-HABP-HA Sepharose complex is pelleted after centrifuging at $1500 \times \mathrm{g}$ for $10 \mathrm{~min}$. The radioactivity of the pellet is counted in a gamma counter. As this radioactivity reversely correlates with the amount of HA in the sample, a standard curve can be constructed and the concentration of an unknown sample can be read from this standard curve.

\section{Results}

The HA concentration for each patient is shown in Fig. 1. In 8 patients with PTM and GO, the mean serum concentration of HA was $21.2 \pm 15.3$ (SD) $\mu \mathrm{g} / \mathrm{l}$. This value is not significantly different from that of the control in whom the mean HA concentration was $25.5 \pm 16.4$ (SD) $\mu \mathrm{g} / \mathrm{l}$. The mean serum HA concentration of Graves' disease with hyperthyroidism without skin or eye involvement was $23.5 \pm$ 11.0 (SD) $\mu \mathrm{g} / 1$ and did not differ from that of the control either.

It is known that the HA concentration increases with age (Engström-Laurent et al., 1985). But the age of the patients in each group was similar, 46.1 $\pm 13.1($ mean $\pm S D)$ years old in PTM and GO, 43.6 \pm 11.3 (mean $\pm \mathrm{SD}$ ) years old in Graves' disease and
$45.6 \pm 11.3$ (mean $\pm S D)$ ycars old in controls, respectively.

\section{Discussion}

It is an interesting question whether abnormal accumulation of $\mathrm{HA}$ in the skin or retroorbital tissue in a patient with Graves' dermopathy or ophthalmopathy can influence its serum concentration or not. But it has long been difficult to answer this question because of the low sensitivity of the assay method. There were trial HA measurements in serum and urine by colorimetric assay (Winand R. J., 1968). But the results obtained were not reliable for two reasons. First, the colorimetry itself is not very accurate. Second, the low sensitivity of the colorimetry required multiple step concentrations of samples. The radiometric assay we have employed for the study is the first commercial kit which enables direct measurement of the serum HA with outstanding accuracy (Engström-Laurent et al., 1985).

The results obtained in the present experiments indicate that the local accumulation of GAG including HA in PTM and 
GO does not increase the serum HA concentration. A possible explanation for our results is that the amount of $\mathrm{HA}$ overproduction in localized skin or retroorbital tissue may not be enough to influence the serum HA concentration compared with that in systemic joints involved in RA. Another possibility is that impaired removal of HA to systemic circulation may play an important part in the accumulation of $\mathrm{HA}$ rather than enhanced production may do.

As this radiometric assay is specific for HA, our results do not exclude the possibility that other classes of GAG such as chondroitin sulfate or heparan sulfate may increase in the patient's serum without increasing the serum HA. But this possibility may be denied in view of the evidences that the histochemical studies showed the accumulation of $\mathrm{HA}$ as, well as sulfated GAG in PTM and GO (Smith T. J., 1989). And we also disclosed that fibroblasts obtained from GO patients produced 2.9 times more HA in culture than those obtained from patients with orbital trauma (Imai et al., 1990).

Our result also indicates that thyrotoxicosis appeared to produce no significant change in the serum HA concentration.

There still exists the possibility that the serum HA concentration of an individual patient undergoes a slight change according to his thyroid, skin, or eye state when examined longitudinally. This aspect is now being studied in our laboratory.

\section{References}

Engström-Laurent, A., U. B. G. Laurent, K. Lilja and T. C. Laurent (1985). Concentration of sodium hyaluronate in serum. Scand. J. Clin. Lab. Invest. 45, 497-504.

Engstroom-Laurent, A. and R. Hallgren (1987). Circulating hyaluronic acid levels vary with physical activity in healthy subjects and in rheumatoid arthritis patients. Arthritis Rheum. 30, 1333-1338.

Fraser, J. R. E., T. C. Laurent, H. Pertoft and E. Baxter (1981). Plasma clearance, tissue distribution and metabolism of hyaluronic acid injected intravenously in the rabbit. Biochem. J. 200, 415-424.

Imai, Y., R. Odajima, Y. Shishiba and Y. Inoue (1990). Studies of Graves' ophthalmopathy : Hyaluronan and proteoglycan synthesized by retroorbital fibroblast. 63rd Annual Meeting of the Japan Endocrine Society, Osaka, 1990 (Abstract $\$ 335 d$ ), in Japanese.

Laurent, U. B. G. and T. C. Laurent (1981). On the origin of hyaluronate in blood. Biochem. Int. 2, 195-199.

Smedsrod, B., H. Pertoft, S. Eriksson, J. R. E. Fraser and T. C. Laurent (1984). Studies in vitro on the uptake and degradation of sodium hyaluronan in rat liver endothelial cells. $B i$ ochem. J. 223, 617-626.

Smith, T. J., R. S. Bahn and C. A. Gorman (1989). Connective tissue, glycosaminoglycans and disease of the thyroid. Endocrine Review 10, 366-391.

Tengblad, A. (1980). Quantitative analysis of hyaluronate in nanogram amounts. Biochem. J. 185, 101-105.

Winand, R. J. (1968). Increased urinary excretion of acidic mucopolysaccharides in exophthalmos. J. Clin. Invest. 47, 2563-2568. 